\title{
National in Form, Socialist in Content: USSR National and Language Policies in the Early Period
}

\author{
Elena Shelestyuk ${ }^{1, *}$ \\ ${ }^{1}$ Chelyabinsk State University, 129 Bratiev Kashirinykh st., 454001 Chelyabinsk, the Russian Federation
}

\begin{abstract}
The article traces the early Soviet national and language policies based on historical, historiographic, sociological, and sociolinguistic sources. The post-revolutionary 1917 policies in the USSR involved autonomy, federalization, linguistic diversity. The 1920s-1930s inaugurated the economic level-off of the outskirts with the center; indigenization of education and administration; development of native literatures, press, theatres; language construction; latinization. The 1930s marked strengthening of Russian (and Union-republican) languages, conceptualization of "convergence in a Soviet nation", cyrillization. We conclude that USSR's national and language policies reveal a pattern fluctuating from liberal (democratic self-governance of nationality territorial units, non-script languages construction, use of nationality languages, development of nationality media, cultures, literatures) to etatist (strengthening of the major nationality language, return to unifying patriotic ideology and education, civic consolidation).
\end{abstract}

\section{Introduction}

Despite a considerable number of works devoted to the Russian and, particularly, Soviet national and language policies in the West, they have often been liable to farfetched and arbitrary interpretations. As V. M. Alpatov points out, the majority of Western works, primarily written by scholars who are not directly Slavicists or Türkologists, are characterized by the lack of knowledge of Soviet material [1].

There are two major trends in the Western interpretation of Russia's national and language policies. The works by L. Laurat, J. Ornstein, E. R. Goodman, C. Humphry, most articles published in the collective volumes Language Planning [2], Sociolinguistic perspectives on Soviet national languages... [3] and the like exhibit the intent of their authors to reduce all the various processes, which took place in the Soviet Union as regards the national and language building, to russification. They disregard such major processes occurring in the USSR as indigenization - statutory conversion of nationalities' governance, culture, education, literature to their native languages, wide involvement of the local population in administrative activities, languages building and normalization, opening of national schools, universities, creation/development of nationalities' literatures and theatres, publication of books, periodicals in these languages, introducing them in mass media etc. - the processes which continued and developed in the 1920s through the 1980s.

The second trend is represented by scholars who often assess the two decades after the revolution positively but criticize the subsequent period as imposition of Russian (T. G. Winner, A. Bennigsen, Ch. Lemercier-Quelquejay, E. E. Bacon, E. G. Lewis, S. Crisp, M. Kirkwood), though among them there are works expressing deserved sympathy for the national and language situation in the USSR (G. Imart, B. Comrie). The sharp division between the "good" 1920 s and the "bad" past 1930 is traced in most nonRussian works on the Soviet language policy. For instance, typical of the collective work [2] is the contrast between S. Crisp's benevolent article on the early period and I. T. Kreindler's rather rigid in tone article on later years. Some of the second category of scholars pay due homage to the theoretical value, methodological accuracy and practical efficiency of the linguistic method, elaborated by Soviet theorists and practitioners of language planning. E.g. V. Reznik [4] argues that “...Soviet linguists' contribution is regarded as one of the earliest examples of a sociolinguistic approach to language, on the one hand, and as a more productive implementation of Marxism in linguistics, on the other." This second group of authors outwardly strive for objectivity, but their conclusions are seldom corroborated by authentic evidence. Then, romanticizing the Soviet language policy of the 1920s-1930s (democratic, but bordering on state interests denial), these scholars do not answer the questions: why is the use of foreign scripts for the languages of the peoples of the USSR considered more democratic than the use of the native Cyrillic script; what language other than Russian (the language of the overwhelming majority) was it natural to apply as the language of interethnic communication in the polyethnic country that was the Soviet Union?

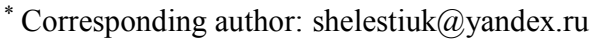




\section{Materials and methods}

We formulate our aim as presenting an objective factual survey of national and language policies of the early USSR, highlighting the major stages, revealing causeeffect connections. This enables us to see both the general patterns of national and language development and how details fit into them.

Our article is based on historical, historiographic, sociological and sociolinguistic sources. The larger part of materials and theoretical sources we use are Russian and those of the national republics of the former USSR.

We use the method of historiographic analysis of sources devoted to national and language policy, the method of sociolinguistic sources analysis, the method of periodization, the chronological method, subsidiary are the discourse analysis and textological methods. We put the evidence gleaned in historical, sociological and sociolinguistic perspectives. We seek to elucidate debatable points from different aspects.

\section{Results}

The USSR's national and language policies reveal a pattern fluctuating from liberal (democratic selfgovernance of nationality territorial units, use of nationality languages, development of nationality media, cultures, literatures, non-script languages construction and normalization) to etatist (strengthening of the major nationality language, return to unifying patriotic ideology and education, civic consolidation).

This pattern depends on cycles of national calm and prosperity alternating with situations of external/internal threats. Besides, the Russian-strengthening trend in the USSR prevailed when there was a focus on modernization and technological progress. There was an urgent need for a language which has accumulated the conceptual-linguistic, terminological and discourse material providing for the up-to-date education, technology and science development, thus the Russian language came to the fore. Russian taught as a language of interethnic communication was intended to be reciprocally beneficial for linguocultures. This was achieved through fiat establishment of linguistic equality principle, consolidation of minority languages, indigenization of all high spheres of communication in these languages, encouragement of publications in them, making them official in their territorial-administrative units.

So it meant not only consolidation of the position of the majority language (Russian) as a science and higher education instrument, but also the mutual conceptual enrichment of ethnic groups and nationalities' languages, based on the practice of translation from/into them of world literature, national and nationality heritage, special texts etc., the enrichment of their terminology and concepts.

\section{Discussion}

Below we expose and analyze the major historical, nationality-construction, language-planning, sociological and sociolinguistic views and data provided in the sources we refer to.

\subsection{Early 20th c. National and Language Issues in Russia: Views, Debates and Practices}

After the 1905 revolution there were arguments how Russian national and language policies should develop. In the State Duma Monarchists insisted on a single state language, law and school; Octoberists recognized equality of rights of all Russia citizens without distinction of nationality or religion, but excluded federalism; Cadets advocated free use of languages and dialects in public life and state-supported non-territorial national cultural associations; Socialist-Revolutionaries (Mensheviks) advocated democratic federal republics with national-territorial autonomies. The Russian SocialDemocratic Labor group (RSDRP, Bolsheviks) advocated the principle of the equality of nations and the right of nations to self-determination to the extent of secession. V. I. Lenin "went all the way from the confidence in the benefits of a unitary state prior to the First World War, to the recognition of the inevitability of the federation..." [5]. He generally advocated larger historical nations-states but demanded full civil equality of nationalities and ethnic groups united by proletarian solidarity.

This dialectic implied policy according to the logic of the moment contingent on expediency for the workings classes. Unalterable were the principles of proletarian internationalism, national equality and democracy. In language policy Bolsheviks proceeded from the same principles. There was assumed to be no mandatory state language ${ }^{1}$. Schools should educate the population in all local languages, and a law should be included in the Constitution protecting the rights of national minorities. Compliant with this idea, in the Soviet period the Russian language was given no official status; the term "language of interethnic communication", entering into use in the 1970s, was never legislated in the USSR [6].

After the 1917 Great October Socialist Revolution, one of the first documents was the Declaration of Rights of the Peoples of Russia, which proclaimed the free development of national minorities and ethnic groups, the right of the peoples of Russia to free selfdetermination, including secession, the cancellation of all national and religious privileges and restrictions.

\footnotetext{
Similar views on the state language were expressed by some scholars, e.g. supporter of Esperanto Professor I. A. Baudouin de Courtenay. He wrote in 1905 that no language should be compulsory for all citizens, but for the reason of minimum time expenditure, the language of the numerically dominant nationality should be the language of central government agencies and the State Duma. However, he never conceded to minor nationalities the right to secession, including his native Poland [1].
} 
In January 1918, the Third All-Russian Congress of the Soviets announced the creation of a new socialist state, the Federal Republic of Soviets of Workers, Soldiers and Peasants' Deputies. It adopted the Declaration of Rights of the Working and Exploited People, which recognized proletariat and peasantry, rather than national groups, as subjects of national relations. The democratic principle was tied in with communist ideological content and the reformation of cultures as "national in form, socialist in content."

On 30 December 1922, the Soviet Union was formed including four Soviet Socialist Republics: RSFSR, Ukrainian, Belarusian and Transcaucasian Socialist Federative Soviet Republics. The Russian Federation included 8 autonomous republics (Turkestan, Autonomous Region of the Germans of the Volga Region, Bashkir, Tatar, Kirghiz, Gorsky and Dagestan, Crimean, Yakut ASSRs), 12 autonomous regions, 2 labor communes. The Bukhara and Khorezm People's Soviet Republics were in a contractual relationship with the Russian Federation. Azerbaijan included the Nakhichevan SSR; Georgia - the Adjara Autonomous Republic, the South Ossetian Autonomous Region, and the Abkhazian SSR, on a contractual basis.

In the 1920s-1930s, the Soviet power made a remarkable effort to boost the economy of the national republics in order to level them off with the center, "create industrial centers in national areas with the maximum involvement of local populations" (J. V. Stalin's Final Word on the Report on National Factors in Party and State at the 12th Congress of RCP(B) April 25, 1923). As the level-off policy was implemented, the industrial base in national republics was established. So, compared with 1913, in 1940 the production of heavy industry increased 6.8 times in Azerbaijan, 7.6 times in Uzbekistan, 10 times in Ukraine, 14 times in Belarus, 27 times in Georgia, 20 times in Kazakhstan.

The assumptions of the Soviet national policy were that the country should be formed as hierarchical structures of nationalities and ethnic groups possessing equal rights. The hierarchy of the republics and regions was based on the principle of the majority of the population and the maturity (ancientness) of an ethnic group. Languages of the peoples concerned fulfilled official functions. There was a notion of a titular nationality - an ethnos after which a national-territorial formation was named (the term "titular" came into wide use only at the end of the Soviet period) [6]. For example: the Ingush people - the Ingush language - the Republic of Ingushetia. A titular nationality of a Union or autonomous republic, together with central authorities, should provide for minor nationalities and ethnic groups the right to education in their native languages and use of them in document management. The lower the rank of a national constituency, the less autonomy it had, but the social functions of local languages were nominally the same: non-titular languages were equal with titular languages, and titular languages were equal with the language of the Union republic of which they were part.
The class principle was unifying, implying workers and peasants' solidarity, equality, unification of social life with self-evident cultural differences. This principle enabled to eliminate conflicts, as there was an integration of sometimes antagonistic entities. Such was the case with Georgia and South Ossetia, just gone through an interethnic war in 1920. The Soviet power established a kind of forced social and ethnic peace there in the form of the Georgian SSR. The strength of that territorial structure was ensured by the consolidating role of the Union center, which supported Abkhazians, Ossetians, Armenians, Azerbaijanis living there. The Georgian SSR was seen as rather unstable [7].

The boundaries of administrative units - Union, autonomous republics and regions - did not strictly coincide with compact ethnic territories, as people migrated, lived intermingled and dispersed, the ethnic composition of cities was different from that of surrounding countryside. The situation was handled democratically, though causing some confusion. If an ethnic area had no sufficiently large settlement, its capital was taken outside, thus the capital of the Adygea Autonomous Region was originally Krasnodar, separated from the Adygea by the Kuban river. The Gorskaya ASSR was divided into the Ossetian and Ingush Autonomous Regions, the capital of both was Vladikavkaz, singled out as a special administrative unit of the North Caucasus. At the same time, Grozny had not been part of Chechnya until 1929, though lying within its territory.

As smaller autonomous regions were created within autonomous republics, the concept of national minority was clarified, defined as any ethnic population living outside their national education or in a non-native environment [6].

There was a task of defining national identities of the population, structuring and fixing administrative boundaries of peoples, served by this or that language. Defining national identities was topical for the peoples of Central Asia and small peoples of the North. In Central Asia, the ethnic principle of administrative division was hard to apply owing to the dispersed settlement of various ethnic groups. The ethnolinguistic composition of Central Asia was complicated, and though people realized their ethnic associations, their leading identity was Muslim. As orientalist V. V. Barthold noted, the peoples of Central Asia felt primarily Muslim, then - residents of a particular city or area; the idea of belonging to a particular nation did not matter to them, as cited in [6]. The Kazakhs until 1925 had been called Kirghiz (Kirghiz-Kaisaks), which reflected their common origin, later they separated. The population of Uzbekistan included many Tajiks and Uigurs, registered as Uzbeks. But intellectuals in linguistically homogeneous regions differentiated between Tajiks and Uzbeks. As for rural population, their identity was more determined by their settlement and kinship, for example, an Uzbek woman from a village, having married a Tajik from Samarkand, said: "I used to be Uzbek, now I am Tajik" [8].

In 1924-1925, the territorial demarcation of Turkestan, Bukhara and Khorezm was made on the

*Corresponding author: shelestiuk@yandex.ru 
ethnic principle, creating new territorial units - Uzbek and Turkmen SSRs. Their autonomous regions Tajikistan, Kazakhstan, Kirghizstan were later given a republican status. Thus, there appeared five union Central Asian republics: Uzbek (1924), Turkmen (1924), Tajik (1929), Kirghiz (1936), Kazakh (1936). The demarcation envisaged ethnic-linguistic, historical, economic, political reasons. Elaboration of literary languages was needed. The Tajik language was based on classical Persian, the Uzbek language was Turkic. Both had many dialects. There was a heated discussion in the 1920s on the choice of the dialects for literary languages (Sart, Kurama or Kipchak).

In the Far North, national okrugs were established for the Chukchi, Evens, Evenks (Chukchi, Sea of Okhotsk, Vitim-Olekminsky, Evenk), and on the territory of Yakutia, which these ethnoses crossed, special national regions for them were created. The Nenets Okrug was formed later, in 1929, and as the development of the Vorkuta Coal Basin began, a part of it was transferred to the Komi Republic (formed 1936).

The area of the Ural Cossack troops, which was the backbone of Kolchak's Ural Army during 1918-1923 Civil War and Intervention, was given over to Kazakhstan, while the areas of Orenburg and Siberian troops were divided between Russia and Kazakhstan [6].

Any minority had the right to its national administrative entity with its own language. Republics, okrugs, regions had city councils and village councils (selsoviets) for minorities. Resolutions were adopted by Sovnarkom (August 29, 1924) lowering population norms for the formation of national units: from 25,000 to 10,000 for city councils, and from 1000 to 500 for village councils. E.g. by 1930 in Ukraine there were 9 Russian, 8 German, 4 Bulgarian, 3 Greek, 3 Polish and 1 Jewish national regions; more than 100 Russian, German and Polish, a few dozen Jewish, Moldavian, Bulgarian and Greek, 13 Czech, 2 Swedish and 1 Belarusian village councils. The Markhlevsky Polish region (population - 41,000) with 73\% Poles, 17\% Ukrainians and $8 \%$ Germans, had 3 German and 2 Ukrainian village councils. Administrative apparatuses in those formations functioned in nationality/ethnic languages, whereas schools gave instruction in republican languages, according to A. I. Klyachin (1989), as cited in [6]. This pattern was observed throughout the USSR. In the Kazakh autonomous republic, in 1928 there were Russian, Ukrainian, German, Cossack, Tatar, Mordovia, Chuvash, Bulgarian, Estonian and Polish village councils, Uyghur, Uzbek, Tajik, Dungan kishlak councils, later they were re-organized into 18 Russian, 2 Uzbek, 2 German and 1 Uighur areas [9]. Ethnic minorities' councils, not constitutionally enshrined, could disappear with the same ease as they were established [6].

In 1933, at the opening session of the CEC, Mikhail Kalinin reported 250 national regions and 5300 national village councils [9]. By 1936 Constitution, the USSR included 11 Soviet socialist republics: Russia, Ukraine, Belarus, Uzbekistan, Tajikistan, Turkmenistan, Kazakhstan, Kirghizstan, Georgia, Armenia and Azerbaijan (Transcaucasian Soviet Socialist Republics).
The Russian Federation included 16 autonomous republics: Bashkiria, Buryatia, Dagestan, KabardinoBalkaria, Kalmykia, Karelia, Komi (Zyryan), Mari, Mordovia, North Ossetia, Tatarstan, Tyva, Udmurtia, Checheno-Ingushetia, Chuvashia, Yakutia.

The national construction of the 1920s laid the foundation for a political system unique in the degree of consideration for the interests of individual nationalities and ethnic groups. The government supported development of ethnic languages and cultures (except religious and "petty bourgeois" aspects).

\subsection{Language Policy in the 1920s-1930s: Indigenization, Latinization, Language Construction}

Bolsheviks' language policy was reflected in a 1918 article by J. V. Stalin, then the People's Commissar of Nationalities of the RSFSR: "Each region shall select the language or languages that correspond to the ethnic composition of its population, and there will be complete equality of languages of both minorities and majorities in all social and political institutions", as cited in [1]. The Russian language did not have the state or official status in the USSR, and the term "language of interethnic communication", which entered into use in the 1970s, was never fixed as a legislation.

The 1920s saw an all-through campaign for the indigenization ("putting down roots", "korenization") of administration, party structures, law, clerical work, education, culture, literature, theatre, etc. making local ethnic languages functionally leading in different republics and regions. The government counted on the broad involvement of local populations in administrative activities. Clerical work was to be conducted in ethnic languages. The Russian population of national republics was supposed to master local languages gradually, partystate functionaries were obliged to learn them.

At the $12^{\text {th }}$ Congress of the RCP(B) (April 1923) Stalin said: "It is necessary that the power of the proletariat should be as dear to ethnically non-Russian peasants, as to Russian ones, that its policy should be clear to them, that it should function in their native language, that schools and authorities should be staffed with local people who know local languages, customs, traditions, ways of life. Only then, and only thereby will the Soviet government, which until recently has been the Russian government, become the power not only Russian, but also international; when institutions and authorities in the republics of these countries speak and function in their native language", as cited in [6]. The Congress resolved to issue special laws that would ensure the use of native languages in all institutions catering for non-Russian populations.

Although the indigenization of ethnic inclusions other than union / autonomous republics and okrugs was reduced to education and culture, the Soviet language policy set a splendid example of enabling ethnicities to develop their identity. So, in the late period of the USSR (before 1991) there were about 130 written literary

*Corresponding author: shelestiuk@yandex.ru 
languages in which education was carried out ${ }^{2}$ - more than anywhere in the world, their speakers living in 15 union, 20 autonomous republics, 8 autonomous regions and 10 autonomous okrugs (districts). The focus on indigenization, including national education, brought its fruit.

Along indigenization, literacy and enlightenment were crucial. Illiteracy was a drag on the fundamental reforms in social relations, economy and culture. According to 1897 census, the population of the Russian Empire was 21\% literate, without children under $9-27 \%$ literate (in Siberia 12\% and 16\%; in Central Asia - 5\% and $6 \%$ respectively) [10]. In 1926, the literacy rate was $3.7 \%$ in Tajikistan, $10.6 \%$ in Uzbekistan, $12.5 \%$ in Turkmenistan, $15.1 \%$ in Kyrgyzstan, $22.8 \%$ in Kazakhstan, 25.2\% in Azerbaijan [11].

Large-scale work on the eradication of illiteracy and semi-literacy began as part of the cultural revolution, which involved universal education, multiplication of primary, secondary and higher educational institutions, circulations of newspapers, magazines, books, allcountry radiofication, promotion of the achievements of high culture among broad masses [12]. In 1933-1937 schools engaged in literacy over 40,000,000 illiterates and semi-literates. By 1940 illiteracy had lost the character of a pressing social problem. According to 1939 census, the number of literates aged 16-50 was $87.4 \%$. By 1950 the USSR became the country of almost universal literacy. This massive push for literacy gave a historic lesson; the increase in the general educational and cultural level of the people, coupled with the broadening of their outlook, became "one of the essential principles of social reconstruction and the transition to a new quality of society" (ibid.). The rapid social development of national regions is evidenced in Jan Gross's study Revolution from Abroad, based on the records of those Poles who had been in Wladyslaw Anders' army. Although the author was anti-Soviet, he admitted that after the establishment of the Soviet Power in the Western Ukraine, "there were more schools, more opportunities for vocational training and higher education, education in the mother tongue, promotion of physical and artistic development... There was a sharp increase in employment - factories and offices required twice as many workers and employees as before the war... It seemed that many of the usual obstacles, hindering the movement upward, had been removed," as cited in [13].

Even small ethnic groups were educated in their languages. At first, the organization of ethnic schools was believed self-regulatory, it devolved on ethnic communities themselves. In the Yenisei Province in Siberia, for example, there came Baltic immigrants and in 192211 Latvian and 10 Estonian schools were added to 2 existing old Tatar schools [9]. Later the state took up organization, with the view to observing interests of every ethnicity and ensuring the reasonable level of teaching.

2 This figure is given by Yu. D. Desheriev [14], V. M. Alpatov [1] gives the figure of 150 languages.
A system of primary schools with ethnoculturallyoriented curricula and instruction in local languages was created, mass education of indigenous teachers was carried out. Textbooks were published in an ever growing number of tongues, in 1934 - in 104 [15]. Ethnic epics, legends and folklore were recorded. Publications of books sky-rocketed, including new-script languages.

Table 1. Distribution of books published in ethnic languages in Russia (1913) and the USSR (1927) [16].

\begin{tabular}{|c|c|c|c|c|c|}
\hline \multirow[b]{2}{*}{ Languages } & \multicolumn{2}{|c|}{1913} & \multicolumn{3}{|c|}{1927} \\
\hline & \begin{tabular}{|c|} 
Numbe \\
r of \\
edition \\
$\mathrm{s}$ \\
\end{tabular} & $\begin{array}{c}\text { Total } \\
\text { circulation }\end{array}$ & \begin{tabular}{|c|} 
Numbe \\
$\mathrm{r}$ of \\
edition \\
$\mathrm{s}$
\end{tabular} & $\begin{array}{c}\text { Total } \\
\text { circulation }\end{array}$ & $\begin{array}{c}\text { Circulati } \\
\text { on } \\
\text { growth } \\
\%\end{array}$ \\
\hline Avar & 3 & 2,800 & 20 & 25,150 & 882.5 \\
\hline Altay & - & - & 26 & 34,560 & - \\
\hline Armenian & 263 & 404,407 & 448 & $1,322,645$ & 327.1 \\
\hline Bashkir & - & - & 87 & 205,450 & - \\
\hline Belarusian & 12 & 33,000 & 401 & $1,327,875$ & $4,023.9$ \\
\hline Bulgarian & 1 & 300 & 12 & 44,500 & $14,823.3$ \\
\hline Buryat & - & - & 39 & 44,400 & - \\
\hline Georgian & 236 & 478,338 & 846 & $2,525,450$ & 528.0 \\
\hline Dargin & 3 & 3,200 & 24 & 23,805 & - \\
\hline Jewish & 574 & $1,541,015$ & 273 & 949,275 & 61.6 \\
\hline Ingush & - & - & 16 & 24,500 & - \\
\hline Kabardian & - & - & 6 & 22,000 & - \\
\hline \begin{tabular}{|l|} 
Kazakh \\
and \\
Kirghiz
\end{tabular} & 37 & 150,300 & 291 & $1,139,323$ & 728.9 \\
\hline $\begin{array}{l}\text { Karachay- } \\
\text { Balkar }\end{array}$ & - & - & 10 & 26,000 & - \\
\hline Kalmyk & - & - & 19 & 51,000 & - \\
\hline Komi & 1 & 600 & 53 & 108,500 & - \\
\hline Kumyk & - & - & 42 & 65,570 & - \\
\hline Lak & - & - & 17 & 13,270 & - \\
\hline Lezgi & - & - & 1 & 2,000 & - \\
\hline Mari & 17 & 27,200 & 46 & 144,000 & 529,4 \\
\hline Moldovan & 1 & 500 & 13 & 33,950 & $6,790.0$ \\
\hline Mordovia & - & - & 63 & 174,690 & - \\
\hline Nogai & - & - & 5 & 11,000 & - \\
\hline Ossetian & 3 & 1,270 & 19 & 28,360 & \begin{tabular}{|l|}
$2,233.1$ \\
\end{tabular} \\
\hline Tajik & 5 & 15,000 & 50 & 198,755 & $1,325.0$ \\
\hline $\begin{array}{l}\text { Tatar } \\
\text { (Kazan) }\end{array}$ & 267 & $1,052,100$ & 374 & $1,518,602$ & 165.3 \\
\hline \begin{tabular}{|l|} 
Tatar \\
(Crimea)
\end{tabular} & - & - & 88 & 220,600 & - \\
\hline Tat & - & - & 2 & 4,000 & - \\
\hline Turkmen & 1 & 1,000 & 85 & 289,091 & - \\
\hline Turkic & 95 & 115,540 & 460 & $1,232,875$ & $1,110.3$ \\
\hline Uzbek & 36 & 85,300 & 302 & $1,402,510$ & $1,644.2$ \\
\hline Uygur & - & - & 3 & 7,500 & - \\
\hline Ukrainian & 228 & 725,585 & 2,418 & $16,572,877$ & $2,228.1$ \\
\hline Finnish & 1 & 10,000 & 72 & 203,119 & \begin{tabular}{|l|}
$2,031.9$ \\
\end{tabular} \\
\hline $\begin{array}{l}\begin{array}{l}\text { Khakassia } \\
\text { n }\end{array} \\
\end{array}$ & - & - & 3 & 5,000 & - \\
\hline Circassian & - & - & 8 & 20,250 & - \\
\hline Chechen & - & - & 21 & 60,000 & - \\
\hline Chuvash & 57 & 106,900 & 83 & 287,800 & 260.8 \\
\hline Yakut & 1 & 1,614 & 20 & 54,140 & $3,354.4$ \\
\hline Russian & 26,029 & $98,819,103$ & 25,183 & $189,576,690$ & 191.8 \\
\hline
\end{tabular}


In Ukraine, 2,764 national schools functioned in 1925-1926, including 1,214 Russian, 625 German, 457 Jewish, 337 Polish, 74 Bulgarian, 31 Tartar, 17 Czech, 5 Armenian, 3 Assyrian, 1 Swedish. Books were published in 11, periodicals - in 8 languages (Ukrainian, Russian, Jewish, Polish, German, Greek, Bulgarian, Tatar). In 1918 the State Drama and the Young Theatre (since 1922 - "Berezil") opened in Kiev, in 1925 the Jewish Theatre opened in Kharkiv, in 1926 - the Polish Theatre in Kiev [6].

Along with schools, there were national literacy points for adults, reading rooms, clubs, "red corners". So, in 1929-30 the Leningrad Region had 274 Finnish, 89 Estonian, 55 Veppsian and 21 Latvian schools; Leningrad had 11 national houses of education - Polish, German, Latvian, Lithuanian, Hebrew, Hungarian, Tatar, Ukrainian, Belarusian, Estonian, Finnish. Only for the Finnish minority 32 reading rooms, 118 "red corners", 14 literacy points were opened. In 1934, the Leningrad Region (including the Murmansk Region) had 24 Veppsian, 10 Ingrian, 4 Karelian, 2 Norwegian and 1 Lapps village reading rooms [9].

In 1929, in the RSFSR there were 85 ethnic teacher-training colleges, 8 pedagogical institutes, national departments in 24 pedagogical institutes. According to 1927 School Census, teaching at primary schools of the RSFSR was in 48 indigenous languages, more than $90 \%$ children of particular ethnicities studied there [17].

In the adjacent Krasnodar Region, Pedagogical University was ukrainized. The Kuban Province had 12 Ukrainian teacher training colleges and 950 schools of the 1st stage. In 1931, 149 titles (968 thousand copies) of books in Ukrainian were released, in 1932 - 600 titles (4.8 million copies) [6].

On the same egalitarian principles, large-scale language construction began. Two major tasks were: 1) normalization based on leading dialects, creating literary standards; 2) development of scripts, alphabetization of languages with no written tradition. The question of oral languages was far from resolved in the former Russian Empire, their scripts and spelling were unstable.

Languages with developed scripts, grammars, norms of usage and written standards were called "oldscript". They were more than 70, including Tatar, Bashkir, Azerbaijani, Kalmyk, Georgian, Armenian, Latvian, Estonian and others. "New-script" languages had previously no written forms, those included 48 languages - Kirghiz, Karakalpak, Abaza, Avar, Adygei, Ingush, Altay, Koryak, Khanty, Khakass, Chukchi and others [6]. E.g. in Dagestan in 1933 there was accelerated development of 11 , and since $1936-12$ languages [3].

National and linguistic construction required enormous financial investment, textbook authors, developers of writing, linguists, philologists, folklorists. In the 1920-1930s, dozens of writing systems developed, many languages first used in office-work, journalism, belles-lettres and legislative-normative fields.

Initially, there was a trend for arabization of the scripts of the Eastern republics and regions of Russia.
Arabic script ("Arabica") already used in Turkic and Iranian languages was reformed, as it had been modified before in pre-revolutionary Russia. Unnecessary graphemes were eliminated, phoneme-grapheme correlation normalized, letter forms unified. A. Baitursunov reformed Kazakh Arabic, designated paired front and back vowels with similar graphemes with a special mark indicating synharmonic rows before words [6].

Since 1930, however, the USSR launched large-scale latinization of languages. This trend had several reasons. Firstly, conversion to a single latinized script was thought to facilitate ideological integration of the society on a diverse language and cultural basis, where the "cultural matter" of nationalities was blended with humanist egalitarian ideology. Secondly, latinization contributed to the breakup with old religious ties, while e.g. Arabica was seen as the script of the Qur'an. S. A. Agamali-oglu, Chairman of the CEC of Azerbaijan, wrote: "Literacy, spread among upper classes, clergy, kulaks, merchants, landlords and Islamic intelligentsia, has migrated to broad working masses. The clergy, connoisseurs of Arab Quranic literacy, have lost influence, so the old script will be lost. The clergy are undeniably isolated in the new world..." [18]. Thirdly, it was seen as a way to break away from traditional (agrarian) ways, to study, facilitate progress and industrialization. Fourth, there was an aspiration for a single language of the peoples of the world, for which the transfer to the Latin script would be the first step, its assimilation would facilitate the world socialist revolution.

N. F. Yakovlev, Caucasian languages expert, head of the Research Institute of the Peoples of the East, claimed that Arabic and Cyrillic scripts were too complex for a universal script, and the right to left direction inconvenient. $\mathrm{He}$ and other scholars supported latinization. E. D. Polivanov wrote in 1928: "The Latin alphabet is $\langle\ldots\rangle$ an international system designed to ensure, firstly, the mutually beneficial convergence of national cultures within the Union, and, secondly, the convergence of graphic communication techniques on the international scale", as cited in [1].

The transition to the Latin script was first tested in Azerbaijan, where the reform of Arabica was abandoned and latinization began in 1922. To develop the latinized New Turkic alphabet, the All-Union Committee for the Development of the New Turkic Alphabet, headed by S. A. Agamali-oglu, was set up in Baku, to be later transformed into the Committee of the New Alphabet. In the first years of the reform the Arabic and Latin alphabets were used on an equal basis, in 1925 the Latin script was made mandatory. Since January 1, 1929, schools, office work, printing in Azerbaijan were fully converted to the new alphabet. The I All-Union Congress of Turkology in Baku (1926) recommended that all USSR nationalities should explore and implement the experience of Azerbaijan [19].

Romanization was supported by the Union Government, there was a special regulation of the Presidium of the USSR CEC of August 7, 1929 [20]. 
The reform headed by N. F. Yakovlev involved joint work of leading linguists, specializing in Caucasian (L. I. Zhirkov), Finno-Ugric (D. V. Bubrikh), Mongolian (N. N. Poppe), Turkic (N. K. Dmitriev and K. K. Yudakhin) and other languages. The polyglot E. D. Polivanov simultaneously engaged in several Central Asian languages, from Uzbek to Dungan.

At first a uniform Latin script for Turkic languages was developed, then individual alphabets, adapted to the needs of specific languages. Alphabets contained from 26 (Yakut) to 35 (Bashkir) letters [19]. They sometimes received unusual graphic conventions, as the letters in the Latin alphabet were insufficient for unambiguous graphic conveyance of Turkic phonemes.

Azerbaijan, Turkmenistan, Kirghizstan, Kazakhstan and other Muslim republics were subjected to latinization. The abandonment of the Arabic script in Bashkiria led to the fall of the circulation of the newspaper "Bashkortostan" from 10,000 to 3600 copies. So, the Bashkir administration urgently re-authorized the use of Arabica for newspapers and record management [1].

There was also latinization in Mongolian and Northern areas. In Buryat-Mongolia Russian Cyrillic was used in the west, the Mongolian vertical script - in the Trans-Baikal region. In 1931 the CEC of BuryatMongolia approved the transfer to the script of the Mongolian People's Republic, but the idea was abandoned and a latinized Buryat script was initiated [6]. In Kalmykia initially vertical, then Cyrillic were used. Since 1931 Kalmyk was also latinized.

A latinized common Northern alphabet was approved in February 1931 [20]. Prior to this, in 1930, the Institute of the Peoples of the North (IPN) was set up in Leningrad, and the Northern Department was opened at Herzen Pedagogical Institute. In January 1932 the AllRussian Conference on the development of languages and writing of the north blueprinted the development of 14 northern languages, proposed by the IPN: Saami, Nenets, Mansi, Khanty, Selkup, Ket, Even, Evenk, Nanai, Udehe, Chukchi, Koryak, Nivkh, Eskimo. It was found necessary and expedient to create literary languages for Itelmens, Aleuts, Nganasans, Yukagirs. Minorities were to use cognate languages: Ents - Nenets, Karagases - Tuvan, Ulchs - Nanai, Orochi - Udehe, Negidals — Evenk [19].

16 languages of the USSR rejected latinization and persisted in the use of civil Cyrillic. In Belorussia the civil Cyrillic script was approved in 1926 by the Institute of Belarusian Culture [6]. Chuvash, Mordvinians, Mari preserved and developed their Cyrillic-based scripts [19]. Georgia consented to change of its original Kartvelian script in 1926 but deferred the implementation of latinized script. Armenia stuck to its ancient script declining latinization.

Romanization negatively affected Altai, Kalmyks, Khakassians, Shor, Vepsians, Izhorians, Karelians, Komi-Perm, peoples of the Far North (Nenets, Evenk, Even, Khanty, Mansi). These peoples used old Cyrillic scripts, created by Russian scholars and Orthodox missionaries, e.g. the Komi-Perm alphabet was developed by Stepan Khrap in the 14th c., reformed by
V. A. Molodtsov in 1918, the Yakut Cyrillic script - in the early 19th c. by O. N. Betling and D. V. Khitrov [19]. Cyrillic was taught at schools, literature was published in it. These peoples were burdened by the newly-introduced latinized alphabet. So, while in 1926 the literacy rate among the Komi was $38.1 \%$, after the latinization it dropped to $15 \%$ [6].

There were attempts to latinize Russian. In 1929, the People's Commissariat of the RSFSR created a special commission on this issue. At its first meeting N. F. Yakovlev declared the Cyrillic (Russian civilian) script a "relic of the $18^{\text {th }}-19^{\text {th }}$ centuries, the script of Russian feudal landlords and bourgeoisie, autocracy, missionary propaganda, great-power chauvinism. It still binds the population with the national-bourgeois traditions of Russian pre-revolutionary culture" [21]. The inevitability of transition to a "single Russian international alphabet" based on the Latin script was proclaimed. A. V. Lunacharsky, Soviet People's Commissar of Enlightenment, in his "Romanization of Russian Writing" [22] emphasized that Latin ensured maximum internationalization, "tying us not only to the West, but also to the renewed East".

By 1940 Latin supplanted Arabic, Mongolian, partly Cyrillic, Yiddish Lashon-Kodesh. All the newly built languages, including the languages of the North were developed on the Latin basis. Yet even supporters of latinization admitted the costliness of the transition to the Latin script: conversion of printing, latinization of most vital books, re-education of people, preparation of cadres [23].

In 1936, the Committee of the New Alphabet published the list of 102 Soviet nationalities, of which only 12 had no written language [24]. 66 alphabets were latinized: Abaza, Abkhazian, Avar, Adygei, Azerbaijani, Altaic, Assyrian, Bashkir, Baluchi, Buryat, Vepsian, Dargin, Dungan, Judeo-Tajik, Ingrian, Ingush, Itelmen, Kabardino-Cherkess, Kazakh, Kalmyk, Kara-Kalpak, Karachay-Balkar, Karelian, Ket, Kirghiz, Chinese, Komi, Koryak, Crimean Tatar, Krymchak, Kumandin, Kumyk, Kurdish, Laz, Lak, Lezghian, Mansi, Moldavian, Nanai, Nenets, Nivkh, Nogai, Ossetian, Persian, Lappish, Selkup, Tabasaransk, Tajik, Talysh, Tatar, Tat, Turkmen, Udeghe, Udi, Uigur, Uzbek, Khakas, Khanty, Tsakhur, Chechen, Chukchi, Shor, Shughni, Evenki, Even, Eskimo. Projects for the latinization of Aleut, Arabic, Korean, Udmurt etc. were drawn up.

Philologists united in the Society of Lovers of Russian Literature criticized latinization. A special commission concluded that the Latin script "does not make communication easier while impeding the study of literary Russian." Yet it was not until 1940 that the latinization was given up and the development of major titular languages on the Cyrillic basis began.

\subsection{0s Shift to Russian As Obligatory School Subject, Cyrillization}

The late 1930s in the USSR witnessed the abandonment of latinization of scripts and the shift for cyrillization. 
The positions of titular languages, especially Russian, strengthened. The reasons for it were various.

Firstly, the previous schemes had proved inadequate for the needs of modernization, molding the peoples of the USSR into a new industrialized and urbanized society: their ethnocultural and ethnolinguistic basis was too narrow for this. Ethnic linguocultures, serving different types of agrarian societies, could not be forced, within a decade or two, to assimilate new content that would provide knowledge necessary for life in an industrialized state. Numerous latinized alphabets for small dialects were created, whose population was illiterate, while they had to be taught on high samples of the written language, which there were none in these languages. Many languages, especially "new-script", could not on their own satisfy the demands of the rapidly developing society. Language development is slow: vocabulary codification and enlargement, grammar sophistication, style differentiation, standardization objectively demand immeasurably greater historical time. A distinct divide revealing this contradiction was the transition from the universal primary education, based on popular national cultures, to the seven-year secondary school, based on the modern system of science and technology. It became clear that it was not a didactic, but general cultural problem. Urgently needed was a linguoculture that could accomplish the mission of modern knowledge conveyance, alongside with the function of interethnic communication of the urbanized population [15]. And objectively, this role was best performed by the Russian linguoculture, which had accumulated a large extent of the world culture of the Modern Times, was well-known and understood. On the practical side, teaching Russian as a second language ensured communication between the peoples of the USSR, their economic and cultural growth, improvement of national cadres in science and technology, necessary conditions for successful military service etc. It also implied enrichment and sophistication of nationality languages due to continued language building policy and languages exchange.

Secondly, from the international perspective, the Soviet leadership was disillusioned with the course for the world communist revolution, which was now viewed as a matter of distant future. The need for a common international script on the European base was no longer seen as urgent. On the other hand, there was an urgent need for the consolidation of the state and its peoples in the face of the possible dangers and threats. The events in Germany since January 30, 1933, when Nazis came to power and declared as their aim the march to the east to capture resources and Lebensraum, greatly contributed to it. The USSR realized the enormous importance of the national question, teaching the country's history and patriotism in the consolidation of the society [25]. "We need the Bolshevik Ilovaisky," was declared at 1934 history conference, referring to D. I. Ilovaysky (18321920), a representative of the conservative-protective trend in pre-revolutionary historiography and journalism and the author of popular history textbooks for high schools, widely published since the $1860 \mathrm{~s}$. New textbooks countering the national-nihilist trend of
M. N. Pokrovsky were published, rehabilitating Russian national heroes Minin and Pozharsky, Alexander Nevsky, Alexander Suvorov etc., Russian men of letters. Religions were partly revived, though on a low scale, relations with the church improved. Unifying patriotic ideology, civic consolidation, "convergence in a single nation" and etatism became major trends.

And here again, the Russian language, culture, reflecting the history of Russia as a multinational state, appeared to be the major means of consolidation. While in the 1920-1930s, all the Soviet languages except Russian were the center of language planning, now, in a single united country, such a center inevitably shifted to the Russian language $[26 ; 1]$.

Thirdly, from the nationalities' perspective, since the beginning of the nationalities building, teaching Russian was not prioritized and even as late as 1936 school syllabuses reduced the number of hours for teaching Russian. In many rural schools of Bashkiria Russian was not taught at all because of the lack of teachers, or Russian lessons were conducted in Tatar or Bashkir (Pravda, 03/20/1938), as cited in [1]. This slowed down and even promised to debunk the literacy and education programs on a high level adequate for the industrialized society. On the other hand, the new educated strata of each national minority, especially their partyadministrative part, were bilingual. They generally welcomed the restrictions on indigenization, because the quality of education at Russian schools was better, so representatives of the nomenclature, regardless of their nationality, preferred to send their children to Russian schools $^{3}$.

Still, the knowledge of Russian in national republics was unsatisfactory, therefore due attention was to be paid to teaching it in national schools. In 1938, a school reform was started following the decree of the Central Committee of the CPSU (B) "On the Study of the Russian Language at Schools of National Republics and Regions." According to it, the learning of the Russian language at schools of the RSFSR was to start in the first year of study, and in other Soviet republics from the second year (the peoples of the North) or from the third year of study. Russian was to be taught till the 5th grade. As for the instruction, within the first stage schools were provided with instruction in their native languages and later - in Russian or a titular language.

The communist-internationalist ideology entailed that the introduction of Russian in the school curricula was accompanied by idealist egalitarian stances. The situation when schools of republics of the USSR and the Russian Federation taught Russian as a mandatory school subject was believed to be temporary, and the use of Russian as the language of instruction was not to be done to the infringement of mother tongues [27].

As to linguistic matters, in the years 1938-1939, a massive shift of the languages of the Russian Federation to the Cyrillic script began. It was preceded by mounting

\footnotetext{
${ }^{3}$ Already in the 1920 s, E. M. Polivanov lamented the refusal of national elites to learn their national languages, accusing them of philistinism [6].
} 
criticism of latinization. Different sections of population railed against the Latin script, rejected latinized newspapers. There were testimonies of some parents demanding: "Do not force this (latinized) language on us. Do not let our children become as disadvantaged as we are" [25]. In 1927, there were protests against the Latin script in Dagestan [1]. Similar remonstrances were expressed by other ethnic minorities. In 1935, it was agreed that all the Northern languages, originally created as Cyrillic, should be translated back into Cyrillic.

The cyrillization of alphabets, graphics went hand in hand with the normalization of spelling in national languages. It was conducted swiftly enough, even though a single state body, like the All-Union Committee for the Development of the New Turkic Alphabet, was not set up. There was no synchrony observed during the first Soviet alphabet shifts: for some peoples it took place in 1937-1938, for others - later. New alphabets were often created "in the field." Even so, the transition from the Latin alphabet to the Russian alphabet was smoother and easier than the first "letter revolutions" [28]. The completion of cyrillization was announced in June 1941. The Cyrillic alphabet was used by many languages of the RSFSR and the USSR.

The transition to the Cyrillic proved fruitful owing to the deep historical foundations, of centuries old tolerant intercultural interaction between the peoples [29]. And, in general, the language building and the script reform in the USSR had uniquely positive consequences, despite the inconvenience of the frequent changes of scripts (Arabic in the 1920s, Latin in the 1930s, Cyrillic in the late 1930s-1950s) and the need to accordingly adjust them to different languages. This inconvenience was offset by the careful examination and refinement of the related languages' systems.

Yet latinization was still the hallmark of the late 1930s. Specifically, for Alexander Pushkin anniversary in February 1937, his works were translated and published in many languages in the Latin script, including rare languages, such as Koryak, Evenk, Circassian, Assyrian, Gypsy etc. [24]. Latin alphabets continued to be created and improved. The latinized Dungan alphabet was published, the latinization continued in Uzbekistan, Kyrgyzstan and Bashkiria [1]. Some latinized alphabets lasted well into the 1950s: in the case of Kazakhstan - until 1940, Uighurs - until 1947, Dungans - until 1953. Georgian, Armenian and Yiddish retained their scripts; the Georgian alphabet was extended to the Abkhaz and Ossetian languages in South Ossetia in 1938.

\section{Conclusion}

Summarizing the above, we should conclude that the national and language policies of the USSR are characterized by diversity: from liberal to stateconsolidating. The ideology, the components of which were proletarian internationalism and the equality of all nationalities, as well as the conservative principle, which determined the attempt to preserve and boost the best and humanist samples of cultural heritage, traditions and values of the numerous autochthonous peoples that made up the variegated national landscape of this country. The consistent Soviet policy in the field of national, linguistic and cultural construction ensured the formation of developed nationalities with rich cultures and developed languages, capable of conveying high cultural meanings and adequately describing the achievements of modern science. Mutual linguistic and conceptual enrichment of the languages and cultures of the nationalities of the USSR was provided, a powerful impetus was given to the flourishing and development of the creative potential of the peoples of the country. The transition in the 1930s to teaching the culturally close Russian language in order to use it as a means of interethnic communication and, partly, as an educational tool played a significant role in this.

The course of the first two post-revolutionary decades, aimed at satisfying the needs of the identity of all peoples, for all its attractiveness and humanity, contradicted the objective situation. The USSR external environment and the level of development at which it was then demanded mutual understanding of the nationalities, and this meant the shift of the Soviet policy towards the ubiquity of the Russian language, the stable development of large regional languages and the topdown maintenance of small languages.

\section{References}

1. V. M. Alpatov, 150 yazykov $i$ politika: $1917-$ 2000 (150 Languages and Politics: 1917-2000), P. 6, 40, 192, 68, 80, 98, 86, 85, 7835 (Kraft+, Oriental Studies Institute of the Russian Academy of Sciences, Moscow, 2000)

2. M. Kirkwood (ed.), Language Planning in the Soviet Union (Macmillan, Houndmills / London, 1989)

3. I. T. Kreindler (ed.), Sociolinguistic perspectives on Soviet national languages : their past, present and future (Mouton, Berlin ; New York ; Amsterdam, 1985)

4. V. Reznik, BASEES 2001 Annual Conference, Fitzwilliam College, Language Policy and Reform in the Soviet 1920s: Practical Polemics against Idealist Linguistics, Cambridge (2001, April 7-9)

5. A. P. Nenarokov (Ed.), Nesostoyavshiisya yubilei. Pochemu SSSR ne otprazdnoval svoego 70letiya? (Frustrated anniversary. Why did the Soviet Union not celebrate its 70th anniversary), Politicheskaya futurologiya... (The political futurology...), Publishing Center "TERRA", Moscow, 35-84 (41, 43, 8), (1992)

6. V. I. Belikov, L. P. Krysin, Sotsiolingvistika (Sociolinguistics) 267, 271, 268, 272-273, 267, 270, 273, 275, 277, 279, 278-279 (Moscow State Humanitarian University, Moscow, 2001)

7. K. Troitsky, Voenno-promyshlennyi kur'er (Military-Industrial Courier), Razdelennyi narod (The Divided People), 7, 273, (2009, February) Retrieved from https://www.vpk-news.ru/articles/4802 
8. O. M. Bronnikova, Etnosy $i$ etnicheskie protsessy (Ethnoses and ethnic processes), Sarty $\mathrm{v}$ etnicheskoi istorii Srednei Azii (Sarts in the ethnic history of Middle Asia), Moscow: Vostochnaya literatura, 151-158 (1993)

9. L. F. Boltenkova, Internatsionalizm $v$ deistvii (Internationalism in action), 63, 157, 156 (Mysl', Moscow, 1988)

10. BSE, Bolshaya Sovetskaya Entsiklopediya (The Great Soviet Encyclopaedia), V. 7: Literacy (Soviet Encyclopaedia, Moscow, 1969-1978)

11. L. M. Zak, M. I. Isaev, Voprosy istorii (Questions of History), Problemy pis'mennosti narodov SSSR... (Problems of writing of the peoples of the USSR...), 2, 3-20 (1966) Retrieved from http://istmat.info/node/42999

12. Narodnoye obrazovanie, nauka i kul'tura $v$ SSSR (People's education, science and culture in the Soviet Union), Collection of articles, 247, Statistika, Moscow (1977)

13. Yu. Emelyanov, Literaturnaya gazeta (Literary Gazette), Press predvzyatosti (Pressure of Prejudice), 32 (6426) Retrieved from http://lgz.ru/article/-32-6426-0708-2013/press-predvzyatosti/

14. Yu. D. Desheriev, Lingvisticheskii entsiklopedicheskii slovar (LED, Linguistic Encyclopaedic Dictionary), Yazyki narodov SSSR (Languages of the USSR peoples), Ed. V. N. Yartseva, Moscow, Sovetskaya Entsiklopediya (1990)

15. M. N. Kuzmin, Russkii yazyk (Electronic Journal "The Russian Language"), Natsional'naya shkola v Rossii v kontekste gosudarstvennoi natsional'noi i obrazovatel'noi politiki (National School in Russia in the Context of the State National and Educational Policy), (2001, August) Retrieved from http://gramota.ru/biblio/magazines/gramota/28 83

16. I. Levin, Kul'tura i pis'mennost' Vostoka (Culture and writing of the East), Materialy $\mathrm{k}$ politike tsarizma v oblasti pis'mennosti «inorodtsev» (Materials for the policy of tsarism in writing of "foreigners"), Baku, VI, 3-19 (1930) NEB [Internet-portal] Retrieved from

https://нэб.pф/catalog/000199_000009_005509739/

17. E. A. Bokarev, Yu. D. Desheriev (Eds.), Mladopis'mennye yazyki narodov SSSR (Newly created written languages of the USSR) (Publishing House of the USSR Academy of Sciences, Moscow-Leningrad, 1959)

18. S. A. Agamali-oglu, Krasnaya Niva (Red Field), Novyi tyurkskii alfavit (The New Turkic Alphabet), 16, 14, (1929) Retrieved from http://www.artinitiatives.org/sites/default/files/articles/kn_16_alfavit.pd $\underline{f}$
19. M. I. Isaev, Yazykovoe stroitel'stvo v SSSR (Protsessy sozdaniya pis'mennostei narodov SSSR) (Linguistic construction in the USSR: the process of creating written languages of the peoples of the USSR) 71, 230, 223-224, 236, 204, 101, (Nauka, Moscow, 1979)

20. A. V. Lunacharsky (Ed.-in-Chief), Literaturnaya entsiklopediya (Literary Encyclopaedia) 1929-1939, Novyi alfavit (New alphabet), Volume 8, Moscow: Soviet Encyclopaedia, 139-142 (1934) Retrieved from http://feb-web.ru/feb/litenc/encyclop/

21. N. F. Yakovlev, Kul'tura i pis'mennost' Vostoka (Culture and writing of the East), Za latinizatsiyu russkogo alfavita (For the latinization of the Russian alphabet), 6, Moscow: VTSK NTA, 27-43 (1930)

22. A. V. Lunacharsky, Krasnaya Gazeta, Leningrad, $\mathrm{K}$ latinizatsii russkogo alfavita (Towards the Romanization of the Russian Alphabet), 6, 20-26 (1930, January 7) Retrieved from http://lunacharsky.newgod.su/articles/latinizacia-russkojpismennosti/

23. E. Zhirnov, Kommersant Vlast', On the romanization of the Russian alphabet, 2 (856), (2010, January) Retrieved from http:/www.kommersant.ru/doc/1301421/print

24. S. M. Dimanshtein (Ed.-in-Chief), Revolyutsiya $i$ natsional'nosti (Revolution and nationalities), 75-85 (CEC of the USSR and the Communist Academy, Moscow, 1930-1937)

25. A. I. Vdovin, Russkie $v X X$ veke. Tragedii $i$ triumfy velikogo naroda (Russians in the twentieth century. The tragedies and triumphs of the great nation), 52,61 (Veche, Moscow, 2013)

26. I. T. Kreindler, Language Planning in the Soviet Union, Soviet Language Planning since 1953, Macmillan, London, 43-63 (1989)

27. F. F. Sovetkin, Izbrannyye trudy (Selected Works), edited by A.O. Pinta. Vol. I, 101 (Saransk, Mordovian Book Publishing House, 1974)

28. V. M. Alpatov, Vostok (East), Yazykovaya politika v SSSR v 20-30-e gody: Utopii i real'nost' (Language Policy in the USSR in the 1920s-1930s: Utopia and Reality), 5, 13-127, (1993) Retrieved from https://istina.msu.ru/publications/article/5596576/

29. V. Bazarova, Vlast' (Power), Eksperimenty yazykovoy politiki pervoy poloviny XX v. (Experiments in language policy in the first half of the 20th century), 8, 94-97 (2009) Retrieved from https://cyberleninka.ru/article/n/eksperimentyyazykovoy-politiki-pervoy-poloviny-hh-v 